PATRICIJA BAJEC, M.Sc.

E-mail: patricija.bajec@fpp.uni-lj.si

IGOR JAKOMIN, Ph.D.

E-mail: igor.jakomin@fpp.edu

University of Ljubljana,

Faculty of Maritime Studies and Transportation

Pot pomorščakov 4, SI-6320 Portorož, Republic of Slovenia
Distribution Logistics

Review

Accepted: Mar. 25, 2008

Approved: July 5, 2010

\title{
A MAKE-OR-BUY DECISION PROCESS FOR OUTSOURCING
}

\begin{abstract}
Should firms perform logistics services on their own or should they buy them from a logistics provider? Today's global competition forces companies to re-evaluate their existing processes, technologies and services in order to focuse on strategic activities. Outsourcing is now increasingly used as a competitive weapon in today's economy. External parties can often do job quicker, cheaper and better. This has resulted in an increasing awareness of the importance of the make-or-buy decision, the dilemma organisations face when deciding between keeping logistics services in house or purchasing them from an outside logistics provider.

This article provides a make-or-buy decision process methodology that any manager can implement - whatever the size or industrial type of the organization. The make-orbuy methodology is one of the most critical strategic decisions within logistics outsourcing and should be taken in a structured and consistent manner. A practical guide to this decision is a step-by-step guide to addressing make-or-buy decision in a consistent and structured manner. The highlevel steps are as follows:

- evaluate whether outsourcing is right for your company;

- determine exactly what functions to outsource and the performance expectations;

- use a well-defined professional selection process to evaluate and select which provider(s) are right for the job.
\end{abstract}

\section{KEY WORDS}

logistics, logistics outsourcing, make-or-buy decision, outsourcing methodology

\section{INTRODUCTION}

The beginning of the $21^{\text {st }}$ century is proving to be an interesting time for the logistics industry. There has been a great deal of transformation in logistics outsourcing caused by the continued drive of manufacturers and retailers to cut costs and by a continued focus on core competencies.

Logistics and supply chain management have often been among the first functions to be outsourced. This has moved beyond the warehousing and trucking functions and spread to ancillary services. Usually, companies decide to outsource some or all of their logistics functions in order to reduce costs, make more effective use of the working capital and focus their energies creating differentiation and promoting revenue growth. In some cases, companies claim they can respond faster and more effectively to change when using a logistics service provider (LSP). Indeed, there are significant benefits to outsourcing logistics.

To maximize these benefits a review of make-or-buy decision must be implemented. The make-or-buy decision is the act of making a strategic choice between producing a product internally (in-house) or buying it externally (from an outside provider). Making the right choice can be the key factor in sustaining a company competitive advantage and is one of the most important tasks of a successful management.

Although the strategic implications of the makeor-buy decision have been discussed for many years these decisions are often made purely on the basis of costs. This paper aims to address this gap by developing a decision-making process that can provide managers with a way of managing the make-or-buy decisions more effectively. The key objectives that arise from the defined purpose are first to describe the set of factors which affect the make-or-buy process, second, to understand better the challenges and barriers that companies face when deciding whether or not to outsource a component or process and third, to suggest some tools and methods for addressing the make-or-buy decision process.

\subsection{Logistics outsourcing defined}

Logistics management has been defined as that part of the supply chain process that plans, implements, and controls the efficient, effective flow and storage of raw materials, in-process inventory, finished goods, services and related information from the point-of-origin to the point-of-consumption (including inbound, outbound, internal and external flows) in such a way as to meet the customers' requirements cost-effectively and ensure that the current and future 
profitability are maximised (Council for Logistics Management, various) [3].

Sourcing is the act of transferring work from one entity to another. Outsourcing is the act of transferring work to an external party. Whether or not to outsource is the decision of whether to make or buy. Organisations are continuously facing the decision of whether to expand resources to create an asset, resource, product or service internally or to buy it from external party. If the organisation chooses to buy, it is engaging in outsourcing. An outsourcing initiative calls for the transfer of factors of production, the resources used to perform the work and the decision rights, or responsibilities for making decisions. The organization transferring these is referred to as a client, the organisation that conducts the work and makes decisions is the vendor, and the scope of the work is captured in a project [7].

With respect to logistics outsourcing specifically, Lynch (2000) provides the following summary: Logistics outsourcing is an arrangement whereby a logistics service provider performs services for a company that could be, or have been, provided in-house. Logistics outsourcing is about subcontracting logistics activities to companies that are equipped to provide the services. According to Rabinovich, Windle, Dresner and Corsi (1999), logistics outsourcing can be defined as long- and short-term contracts or alliances between manufacturing and service companies and third-party logistics providers (3PLs). Ravi (2001) points out that the outsourcing of logistics functions is a business dynamic of great importance for many shippers and that it involves the use of external companies (i.e. third parties) to perform logistics functions that have traditionally been performed within an organisation [3].

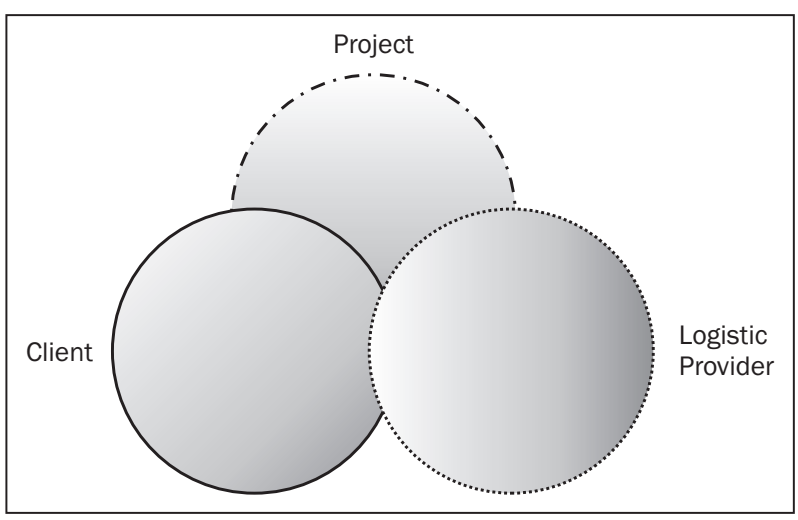

Figure 1 - Components of outsourcing

Source: Power, Desouza, Bonifazi [7].

\subsection{Evolution of logistics outsourcing}

To understand profoundly the outsourcing, there are four levels of logistics outsourcing. Figure 2 illustrates how this evolution has progressed over the last 30 years:
1. In-house logistics, or insourcing logistics means that the company operates its logistics activities inhouse. The company owns transport, warehouses, handling equipment, and others including staff to process the logistics functions.

2. Logistics service provider (LSP), or asset-based logistics (2PL) is the management of traditional logistics functions such as transport and warehouse. The company who does not own or have enough facilities and infrastructure may hire an LSP to provide the vehicles or the basic service. The major reason is to reduce the cost or capital investment.

3. Third party logistics (3PL/TPL), or contract logistics. TPL in the original term means using of external organisations to perform the logistics functions that can be the entire logistics process or selected activities. A relationship is characterized by a longer-term, more mutually beneficial relationship.

4. Fourth party logistics, or supply chain logistics is an evolution of supply chain outsourcing. It manages and integrates all kinds of resources and oversees 3PL functions throughout the supply chain with the sense of global market, strategic advantages and long-term relationship [2].

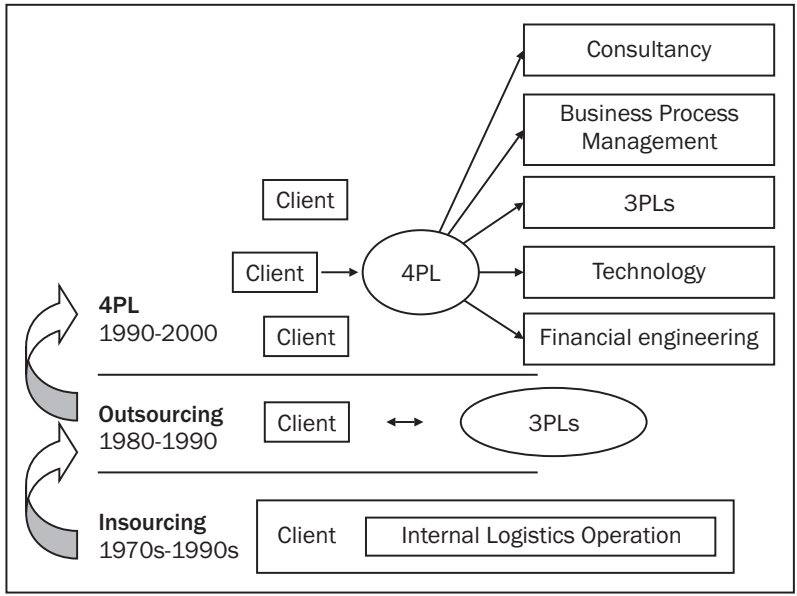

Figure 2 - Evolution from in-house logistics to various outsourcing models

Source: Gattorna, Selen, Ogulin [1]

The ever increasing competition in today's global markets, introduction of new products with shorter lifecycles, faster dissemination and proliferation of information, and higher expectations of customers have forced enterprises to invest in and focus attention on the entire supply chains. The convergence of technology and the rapid acceleration of e-capabilities have raised the need for an over-arching integrator for supply chain-spanning activities.

The logistics service providers have been keen on contributing to innovations in their client's supply chain for some time and they have been expanding service offerings for example through the creation of 4PL offering. The fourth party logistics service provider 


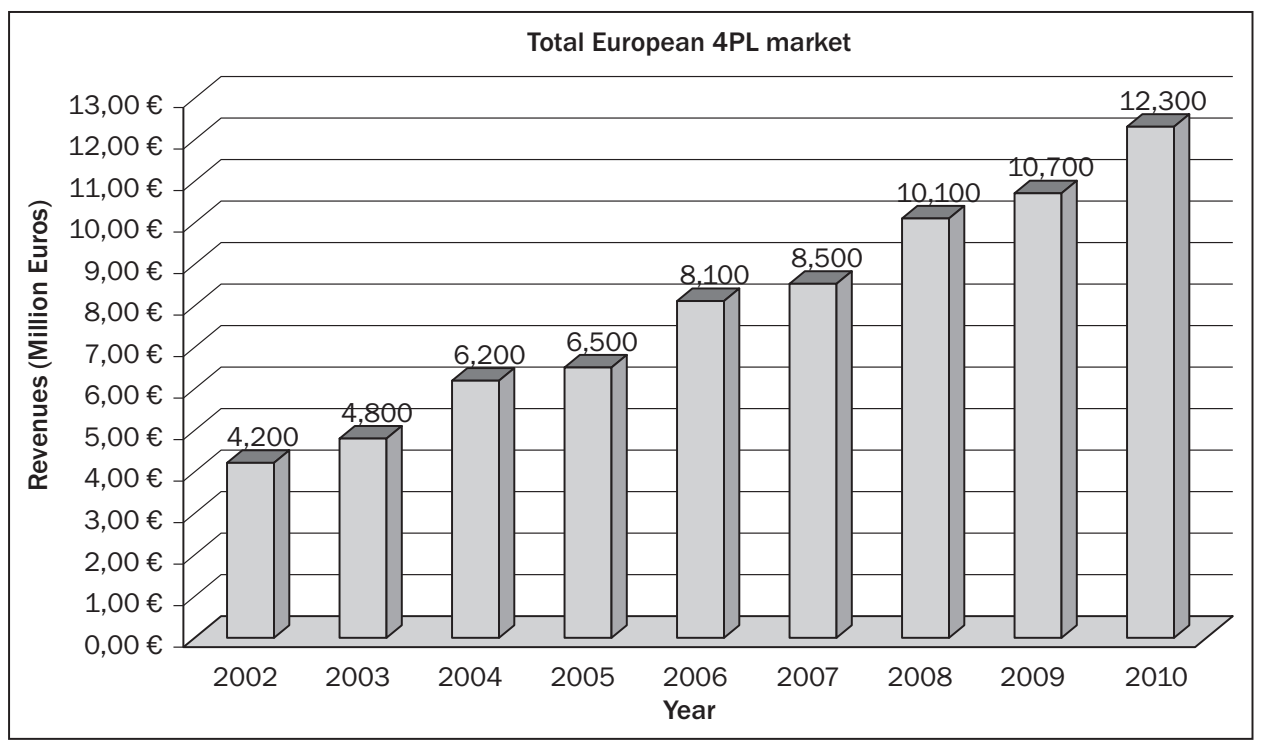

Figure 3 - Growth of European 4PL market

Source: M. Williams [8]

(4PL) participates in supply chain coordination instead of just providing operational logistics and fulfillment services, like a traditional third party logistics provider (3PL) would. The 4PL model essentialy elevates the SPL to a coordination of the flow of goods, rather than just an operator in the physical movement of goods. This is seen by 3PLs as a method for not only increasing revenues but also, more importantly, as a method to contribute to offering higher value added activities in the supply chain than the warehousing and transport services traditionally did [9]. The idea of using a $4 \mathrm{PL}$ was slow in gaining traction. Now, as a result of globalization, 4PLs are fast gaining momentum and there is a considerable potential for growth in this sector.

\section{FOUR STAGES PROCESS MAKE-OR-BUY-DECISION}

The decision of whether to make or to buy is a problem that is frequently encountered by higher managers who want to reveal and exploit every competency within the links of the supply chain. Make or buy is a decision not to be made only on the basis of economic considerations, since acquisition or loss of core competencies may also be involved.

Decisions regarding outsourcing significant functions are among the most strategic that can be made by an organisation. They address the basic organisational choice of the functions for which internal expertise is developed and nurtured and those for which such expertise is purchased. Even an individual make-or-buy decision can affect company's production methods, working capital, cost of borrowing or competitive position.
Outsourcing provides companies with the freedom to concentrate their energies on key activities that are critical to maintaining their competitive edge. This results in improvement of industrial relations and rising labour productivity.

For activities eligible for outsourcing, the key strategic question is whether the firm can perform those service activities on a level that is comparable with the best organisations in the world. If a service activity meets several criteria, the next step is deciding whether the service is central to the firm's core strategic activities. Moreover, to make the best make-or-buy decision, companies must determine how that decision will affect the final product quality and the company's technology [4].

The following are the suggested stages to successful make-or-buy decision:

- building incentive for outsourcing,

- exploring strategic implications,

- analyzing costs/performance,

- selecting providers.

\subsection{Planning stage}

As with any significant new planning activities also by planning initiative team member selection, the leader selection and outside adviser come into play. The project team assesses the risk and the resources, information and management skills needed to mitigate those risks, while the outsourcing adviser levels the playing field with the outsourcing providers [6]. The feasibility of outsourcing is determined by a series of screenings that every outsourcing initiative should pass before further, detailed evaluation:

1. Senior management and employee announcement: Because outsourcing involves a number of 


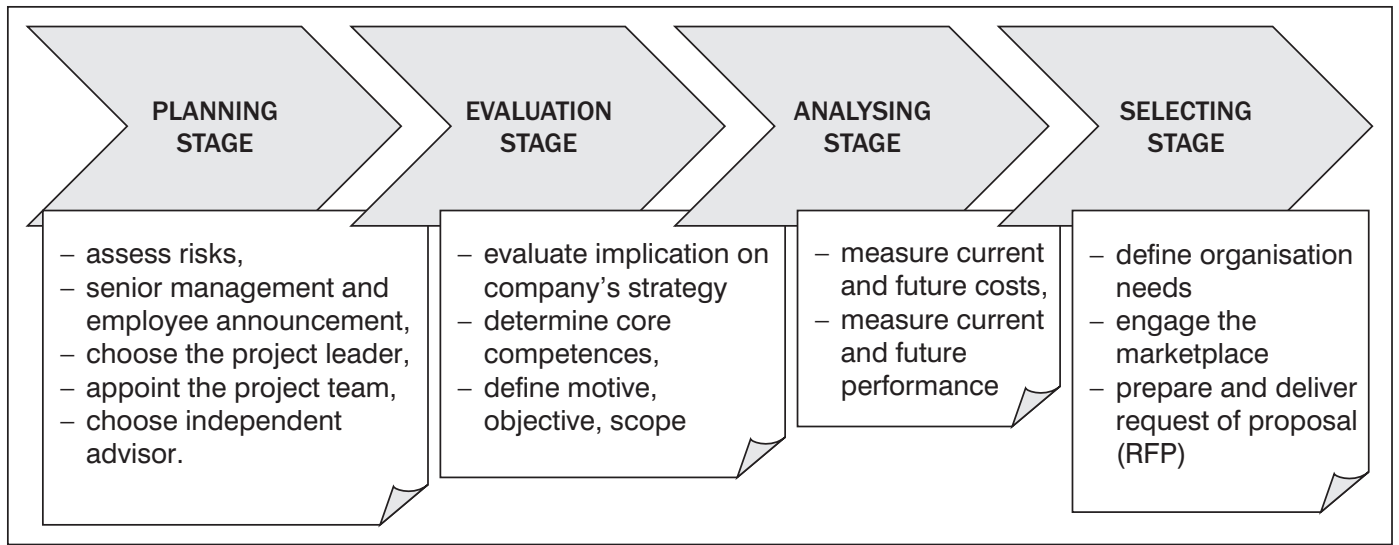

Figure 4 - Four stages in the make-or-buy decision process

strategic issues, as well as significant risks and rewards, senior management's clear and unequivocal stated support is prerequisite. For larger outsourcing initiatives top management must play a role. For smaller initiatives, middle-level managers might do the heavy lifting with the support of senior management. The team usually needs a mix of managerial and technical talent and representatives from user areas whose services will be directly impacted by outsourcing. User perspectives and objectives are essential for setting the scope and assessing the risks. Before selecting the project team and advisers the organisation must inform also the employees about the outsourcing initiative, explain why outsourcing should be explored and indicate that this is only a test to determine if outsourcing is a viable tool. If they do not know what is happening, they may react very negatively to outsourcing.

2. Choosing the project leader: Early in the outsourcing evaluation process, the customer must identify who will take the leadership responsibility, perform the analysis, and make the decisions. The role of the outsourcing project leader is complex and challenging. It runs from managing the project, the team, and the individual team members to gathering technical support, facilitating discussions, and drawing out consensus to drafting reports, making presentations and so on [6]. In selecting the individuals for this position, the following characteristics should be considered: (1) ability to embrace and champion change, (2) earned credibility across the organization, (3) a desire to manage, not to do, (4) the ability to build trust, (5) strong communication skills, (6) strong negotiation skills, (7) strategic planning skills, (8) project and team management skills, (9) marketing skills, (10) process expertise [5].

3. Appoint process implementation team: Choosing team members is a critical step in successful outsourcing. Characteristics and skills that the outsourcing team members should possess are the following: (1) motivation to participate, (2) a record of delivering on promises, (3) strong communication skills, (4) ability to think creatively and strategically, (5) solid performance evolutions, (6) relevant specialization within the organization, (7) wide experience from outside the organization. The team members should be objective. They should represent a cross-section of the organization's functions and should have access to and full cooperation of the individuals in the areas to be considered for outsourcing [6]. The size of the customer's team depends on the scope and size of the project, but smaller teams are generally more effective. The team can be quite small in the planning phase and expanded when the analysis begins. Teams with full-time members are often more focused and effective than teams composed of people who work part-time, although full-time allocation may only make sense for large outsourcing projects. It helps tremendously to have persons experienced in outsourcing on the team for the insight they bring to the issues and the realism they bring to cost and benefit estimates.

4. Choosing an independent advisor: Independent outsourcing advisors can help avoid failures. They will have seen different situations first hand and can help the client avoid the same pitfalls. Lack of planning, lack of follow-up in execution, miscommunication, not understanding cultural differences, poor process, etc., are just a few of the areas that an outside advisor can help with. If a client has not established an offshore outsourcing relationship, having an independent advisor can help formulate clearly articulated objectives and bring their expertise to the table with regard to process, selection, contract negotiations, and getting the transition going in an accelerated manner. Another benefit of an outside advisor is to help the client understand if they are getting a good deal (compared with the industry and other clients doing similar work with a similar type of outsourcer). 
This removes one potential area of mistrust in the relationship. Also, advisors who have people with good understanding of the outsourcer's national culture can explain the cultural differences. There are steps one can take to avoid these problems. Independent advisors can most certainly help in establishing, repairing, maintaining, and improving client/provider relationships.

\subsection{Evaluation stage}

If the outsourcing idea has passed the initial screenings, planning can proceed to a detailed outsourcing evaluation:

1. Outsourcing implication on organizational vision and structure: Early in the outsourcing evaluation process, the customer must find out and understand how outsourcing can fit within the organisation's strategies (organizational structure and vision) and how its implementation will affect those strategies.

2. Determining core competences: Core competencies are the source of competitive advantage and arise from the integration of multiple technologies and the coordination of diverse production skills. To achieve long-term growth, companies need to develop, protect, and leverage their core competencies and consider outsourcing any activities that do not confer a competitive advantage. If the function or functions to be outsourced contribute in central ways to the organization's competitive success (core competencies) then those core functions are probably not strong candidates for outsourcing. Identifying which resources and capabilities to preserve and which activities to outsource, requires careful consideration and planning.

3. Defining the motive, objectives and scope: Before serious analysis of cost and performance can take place, the company should know the objectives of outsourcing and know the scope of what is to be considered for outsourcing. If the company does not know what it is trying to accomplish, any alternative can look good or bad. Companies that rush into outsourcing without fully understanding what they hope to gain soon find themselves in a mire of contractual battle or not receiving improved services. Sensible reasons to consider outsourcing are both strategic and tactical. It is essential to know and clearly define the objectives of the company and to document what the company expects from outsourcing. Clear objectives help lead to a sound decision on what to outsource and what not to outsource. The objectives for outsourcing are often derived directly from the motives for outsourcing that can be grouped into a few summarised categories: (1) concentration on core business, (2) investment reduction, (3) restructuring of the supply chain, (4) cost reduction and service improvements. Specifying outsourcing objectives that are more specific than the motives provides a basis for developing selection criteria for the provider and guides the requirements and conditions in the RFP and provides a common understanding for the persons who write the RFP, evaluate the proposals, and recommend the selected supplier(s). Objectives also provide the basis for evaluating provider proposals. The last important thing to be defined is the scope. Outsourcing can be divided into two general categories: total and selective. Total outsourcing involves contracting out $80 \%$ or more of the function. Selective outsourcing involves outsourcing a few functions that total less than $80 \%$ of the whole. Methods for identifying functions that might be selectively outsourced include opportunistic, problem-focused approaches and more methodical planning approaches.

\subsection{Internal costs and performance analysis}

The goals of this phase are to develop detailed cost analysis of the target function. When considering outsourcing part or all of any business process the following associated costs need to be taken into account: salaries, benefits, training/education, specialised software, travel, phone charges, depreciation/ amortisation, mail costs and postage, office supplies, equipment, management time, information costs, occupancy charges.

It is essential that the project team conducts activity-based analyses in order to understand the current costs of the activities that might be outsourced and those that are staying. To this are added the costs of invested capital and the estimated costs of poor performance [6]. The biggest challenge is to develop both costs and service requirements in light of expected technological and business change (which may be interrelated) over the expected life of the outsourcing arrangement. Forecasting the future is always difficult and often inaccurate, but still necessary. The project team must estimate which costs do not disappear with outsourcing and what new costs will be incurred as result of outsourcing. Without a good idea of future needs and the costs of meeting these needs, it is difficult to outsource effectively and efficiently.

There are also financial benefits resulting from outsourcing and they are other than cost-related. These are estimated and used in the make-or-buy decision [6].

Current performance should also be measured and analyzed, since performance improvement is often a reason for outsourcing. The project team estimates the financial impact of the internal poor performance and projects future performance. Understanding the 


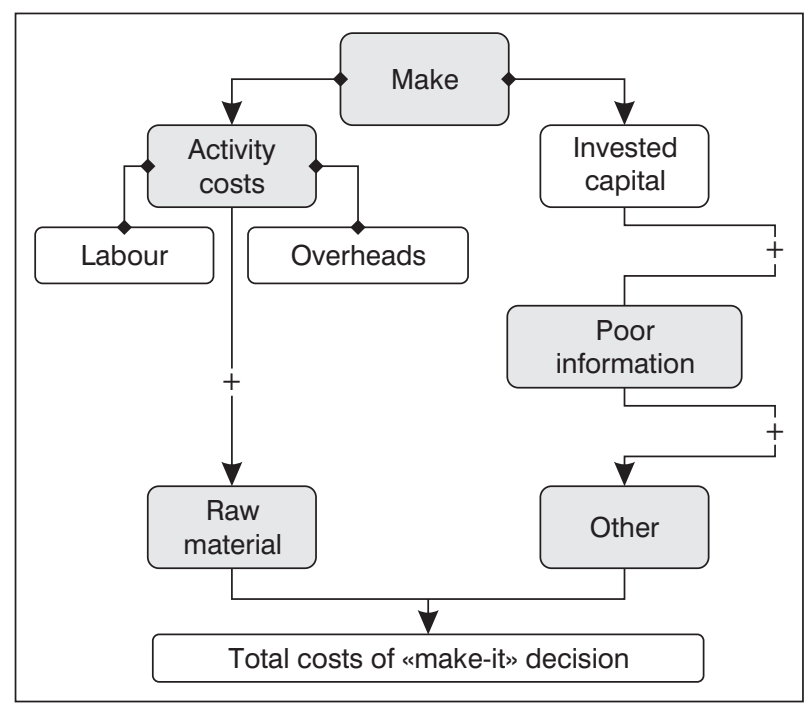

Figure 5 - Financial element of "make-it" decision Source: M. F. Greaver [6]

existing performance is fundamental to setting provider performance standards and monitoring their performance [6].

Once a company has estimated all the costs, it determines its position on who will bear each cost - the organization or the outsourcing provider, as shown in Figures 5 and 6.

\subsection{Selecting service provider}

This process of first defining organisations needs, then engaging the marketplace of providers, preparing and delivering request of proposal (RFP) and ultimately selecting the right provider requires a good interplay of internal assessment, coupled with an effective and practical interaction with the marketplace of potential providers [5].

Once a decision has been made on which areas to consider for outsourcing, the project team should begin researching the providers. Following are a number of ways how to proceed in identifying potential providers: - open a dialogue with outside organizations the company is already doing business with,

- use the organization's professional network,

- direct research,

- use consultants [5].

The project team lists the criteria for "qualified" providers based on the reasons for outsourcing. Potential providers are identified and further investiga-

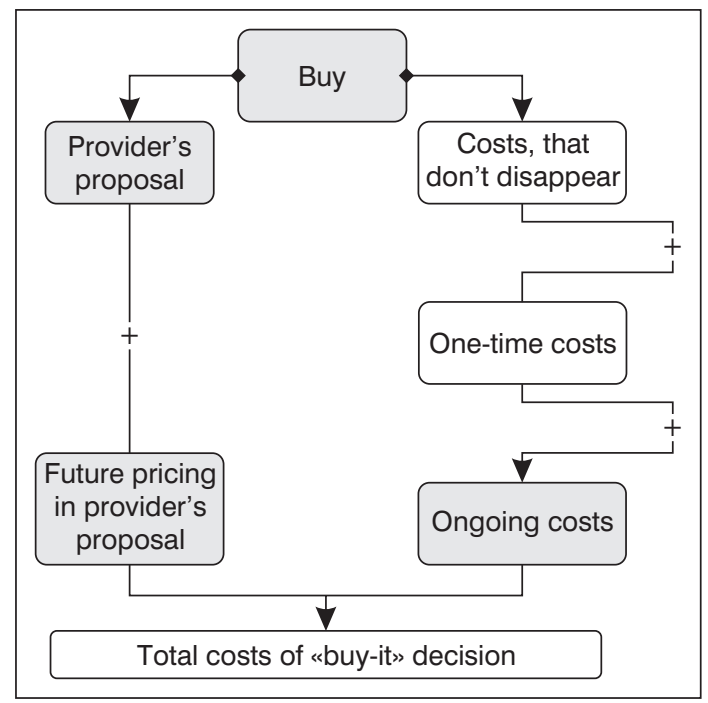

Figure 6 - Financial element of "buy-it" decision Source: M. F. Greaver [6]

tions are made to determine their qualification. Their qualifications are then compared to the criteria and a decision is made on whether they should be invited to submit proposals. Requests for proposal are prepared and delivered to the targeted providers list and should include the reasons for outsourcing, scope of outsourcing, qualifications of providers, pricing models, performance measures. When the proposals are returned, they are evaluated and compared to the other proposals and further discussions are held with the providers on the short list. From this short list the prime provider is selected [6].

\subsection{Decision time}

This is the step where the oversight of the project team and top management comes into active play. The goal here is to review the information gathered till this phase and to consider the recommendation on whether the service should be made internally or outsourced. If the decision is to buy the part family from an outside source (or sources), then the four steps shown in Figure 7 should be undertaken.

\section{CONCLUSION}

The recent times have witnessed an increased global interest in outsourcing of logistics functions.

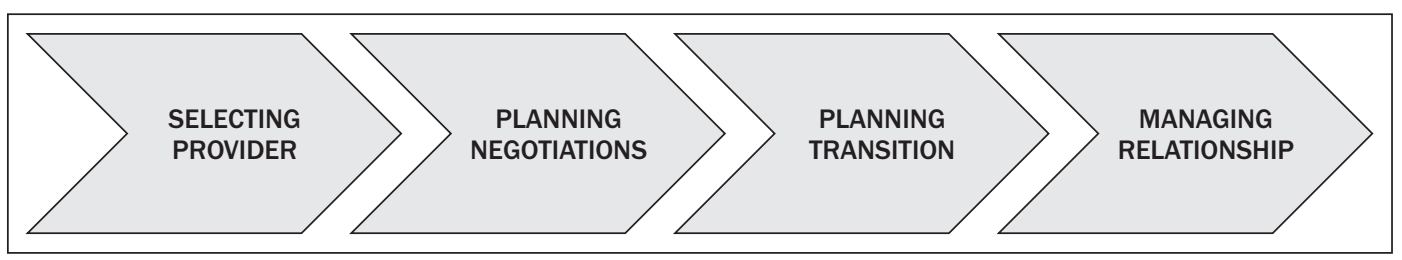

Figure 7 - Additional four steps of complete outsourcing process 
The outsourcing process is very complex and has to be planned, well organised, calculated and performed in the best possible way to gain the expected success.

Determination whether to produce logistics services internally or to buy them from an outside logistics provider involves both qualitative and quantitative factors. Qualitative considerations include service quality and the necessity for long-run business relationships with subcontractors. Quantitative factors deal with cost.

The steps of the make-or-buy decision should be modified to fit the specific organization and outsourcing situation. These decisions are always individual decisions, which have to take into consideration the specific characteristics of each company. The establishment process depends on the type of industrial sector, complexity and scope of activities. This means that the establishment of a general model, which will be useful for all organisations makes no sense.

\section{Mag. PATRICIJA BAJEC}

E-mail: patricija.bajec@fpp.uni-lj.si

Dr. IGOR JAKOMIN

E-mail: igor.jakomin@fpp.edu

Univerza v Ljubljani, Fakulteta za pomorstvo in promet Pot pomorščakov 4, 6320 Portorož, Republika Slovenija

\section{POVZETEK}

\section{POSTOPEK ODLOČITVE "NAREDI SAM ALI KUPI"V PROCESU OUTSOURCINGA}

Naj podjetja sama izvajajo logistične storitve ali naj jih kupijo od logističnih izvajalcev? Dandanašnje globalno konkurenčno okolje sili podjetja $v$ ponovno ovrednotenje svojih obstoječih logističnih procesov, tehnologij in storitev znotraj podjetja, z namenom osredotočenja na strateške aktivnosti. Outsourcing se tako pospešeno uporablja kot konkurenčno orožje $v$ današnji ekonomiji, saj lahko zunanji izvajalci pogosto opravijo delo hitreje, ceneje in bolj kvalitetno. Temu logično sledi tudi povečana zavest o pomembnosti odločitve "naredi sam ali kupi", dilema s katero se podjetja soočajo, ko se odločajo med ohranitvijo izvedbe logističnih storitev znotraj podjetja ter med izločitvijo izvedbe logističnih storitev $v$ roke zunanjemu izvajalcu.

Članek nudi splošno metodologijo odločitve "naredi sam ali kupi", ki je uporabna vsem managerjem, ne glede na velikost ali industrijsko panogo podjetja. Odločitev "naredi sam ali kupi" je ena izmed najbolj kritičnih strateških odločitev v okviru logističnega outsourcinga, zato mora biti izpeljana na strukturiran in dosleden način. Eden izmed praktičnih postopkov, ki podpira tak način izpeljave odločitve je izvedba korak za korakom. Najpomembnejši koraki v okviru te izvedbe so sledeči:

- Ovrednotiti ali je outsourcing primeren za podjetje.

- Natančno določiti funkcije, ki jih podjetje namerava izločiti v zunanje izvajanje ter pričakovanja podjetja glede same izvedbe.

- Uporabiti dobro definiran strokoven proces, ki bo pomagal ovrednotiti pravo izbiro zunanjega izvajalca.

\section{KLUUČNE BESEDE}

logistika, logistični outsourcing, odločitev "naredi sam ali kupi", metodologija outsourcinga

\section{LITERATURE}

[1] J. Gattorna, W. Selen, R. Ogulin: "Characteristics, strategies and trends for 3PL/4PL in Australia, Alpha Research Consortium, Sydney, Australia, March 2004

[2] J. Ge, L. Ding, N. Bussayadilokskul, L. Zhang, B. Han, Z. Cai: Outsourcing Logistics Services Including 4PL, Logistics \& Supply Chain Management Summer School, Sydney, Australia, May 2004

[3] J. K. Beverly: An investigation into logistics outsourcing practices, trends and issues within the manufacturing sector in South Africa, Ph. D. thesis, Rand Afrikaans University, Johannesburg, South Africa, 2003

[4] L. G. Laios, S. J. Moschuris: "Make-or-buy Decisions - Major Factors to Consider", Journal of Supply Chain Management, 2004, pp. 85-87

[5] M. F. Corbett: "The Outsourcing Revolution: Why it makes sense and how to do it right", Dearborn Trade Publishing, Chicago, 2004

[6] M. F. Greaver: "Strategic Outsourcing: A Structured Approach to Outsourcing Decisions and Initiatives" AMA Publications, New York, 1999

[7] M. J. Power, K. Desouza, C. Bonifazi: "The Outsourcing Handbook: How to Implement a Successful Outsourcing Process", Kogan Page Limited, London, 2006

[8] M. Williams: "3PL, 4PL, LLP - is there a real difference and what is the future", Presentation to an invited audience, Coventry, UK, March 2006

[9] R. I. van Hoek: "UPS Logistics and to Move Towards 4PL - or Not?", Logistics Research Network Annual Conference, Philadelphia, US, October 2004 